\title{
ROLE OF RELIGION IN PEACEBUILDING AND SOCIAL COHESION IN BORNO STATE, NIGERIA
}

\author{
${ }^{* 1}$ Abubakar, A. \\ ${ }^{*}$ Centre for Peace, Diplomatic and Development Studies, University of Maiduguri, Nigeria \\ *Corresponding Author Email: abubakaramsami@gmail.com Phone: +2348058310614
}

\begin{abstract}
One basic component that represents a genuine danger to International Peace and Security was and is Ethno-Religious situated clashes in a profoundly divided society. Ethno-Religious clashes in Iraq, Syria, the Central African Republic, Myanmar, Nigeria, South Sudan and Ukraine among others pull in worldwide consideration and present horrible situations of mass abominations in the influenced state. This paper explores a critical question, what can religious actors do to help deeply divided societies rediscover a sense of living together and building long term peace in the wake of identity-based violence? The objective of this paper is to examine the role of religion in peacebuilding and social cohesion. This paper employs the multidimensional approach of research which is in pursuit of truth, and also the paper relies mainly on research works such as thesis, dissertations, research journals, newspapers and magazines. The finding reveals that religious actors play a critical role as a stakeholder in peacebuilding in deeply divided societies to rediscover a sense of living together and building long term peace in the wake of identity-based violence and should be involved at all stages of the peace process. The study recommends that the Borno State Government should engage religious actors or faith-based organisations in formulating a policy program that is directed towards promoting social coexistence in a deeply divided society like ours to improve social well-being as well as critical drivers of sustainable development, peace and security.
\end{abstract}

Keywords: religion, peacebuilding, social cohesion, peace

LICENSE: This work by Open Journals Nigeria is licensed and published under the Creative Commons Attribution License 4.0 International License, which permits unrestricted use, distribution, and reproduction in any medium, provided this article is duly cited.

COPYRIGHT: The Author(s) completely retain the copyright of this published article.

OPEN ACCESS: The Author(s) approves that this article remains permanently online in the open access (OA) model.

QA: This Article is published in line with "COPE (Committee on Publication Ethics) and PIE (Publication Integrity \& Ethics)". 


\section{INTRODUCTION}

Ethno-religious tensions are one of the major threats to International Peace and Security most especially in deeply divided societies. Ethno-Religious clashes in Iraq, Syria, the Central African Republic, Myanmar, Nigeria, South Sudan and Ukraine among others pull in worldwide consideration and present horrible situations of mass abominations in the influenced states. In such circumstances, when assumed sense fellowship vanishes, then destructive viciousness emits and frequently solidifies along strict partisan or ethnic lines. Without separations, in any case, (Fletcher and Catharine, 2014) when the weapons fall quiet, groups in such social orders are compelled to keep living respectively in a shared, however constantly challenged way.

Since 2010, incidents of violence with religious, ethnic, or sectarian dimensions appear to be on the rise, reversing the overall trend of a steady decline in armed conflict more generally, and identity-based conflict, in particular, that characterized the post-Cold War era. In a deeply divided society, religious and ethnic-oriented violence continues to present grave threats to international peace and security (Fletcher and Catharine, 2014).

As a part of the social and political aspect of human life, conflict is inherent and legitimate. However, conflict turns violent in many circumstances, causing grave damages in terms of lives and properties. The costs and consequences of conflict become highly unacceptable as it destroyed the social fabric of the society (Ramadhan, 2015).

Many scholars viewed religion as a motive for conflict as it emerged as a critical component in many past and present conflicts. Religion does not always, however, drive conflict, but it is also an integral factor for the peacebuilding and post-conflict reconciliation process. Connectivity between religion and violent conflict is easy as most of the world's violent outbreaks, both present and past, are couched in religious terms. This is evidenced by the contemporary conflicts in Sri Lanka, Nigeria, Iraq, and Israel/West Bank/Gaza (USAID, 2009). Also, connecting religion and peacebuilding is equally easy as religiously motivated actors acted in extraordinary ways to bridge divides, promote reconciliation, or advocate peaceful coexistence (USAID, 2009). It thus becomes clear that understanding the dynamics of conflict both the sources of discord and the forces of resilience requires an understanding of the connections between conflict, religion and peacebuilding.

However, since independent of Nigeria, Borno, home of peace as it's popularly called, remained one of the peaceful states in the country except for cross border banditry during the rainy season, as the state is only part of Nigeria that shares boundaries with three countries - Cameroun, Chad and Niger Republics, whose history are turbulence throughout. The state experiences the Maitastine conflict in 1982 which was a spillover of conflict that originally started in Kano (Abubakar, 2016).

In 2002, what was known as the Boko Haram movement emerged under the aegis of an Islamic Movement called Ta'ifatul Mansurah, meaning the winning team. At the early stage, the movement was known and called the Nigerian Taliban by the general public. The word Taliban was derived from the Arabic word 'Talib' meaning 'student' (Abubakar, 2016).

As a result of the emergence of the group in 2002, they're a lot of confrontations with government forces which eventually led to the death of Yusuf, the groups' spiritual leader and some other top-ranking members in 2009.

Since 2009, insecurity as a result of the Boko Haram insurgency has led to the loss of over 20,000 lives and the $\mathrm{d}$ isplacement of over two million people. Throughout the state, Livelihood has been disrupted, and homes, public 
buildings (schools, hospitals, markets) and infrastructure including farmlands destroyed, livestock killed (FGN, 2016).

There is a process, led by the Government of Borno in collaboration with the Federal Government of Nigeria, supported by local, national and international partners, helping in identifying the physical, social and economic impacts of the conflict in Borno State, and will inform the process of stabilisation, peacebuilding and economic recovery.

In the peacebuilding process, there are quite several religious/faith-based local and international NonGovernmental Organisations (NGOs) as well as Civil Society Organisations that are working in collaboration with the Federal and State government to promote peacebuilding and social cohesion in Borno state. Some of these NGOs and Civil Society Organisations include; Catholic Relief Services, Christian Aids, Federation of Muslim Women Association (FOMWAN), among others.

\section{OBJECTIVE OF STUDY}

The objective of the study is to examine the role of religion in peacebuilding and social cohesion. The paper explores a critical question, what can religious actors do to help deeply divided societies like Borno state rediscover a sense of living together and building long term peace in the wake of identity-based violence? And also, to advise Borno State Government to engage religious actors or faith-based organisations in formulating a policy program that is directed towards promoting social coexistence in a deeply divided society like ours to improve social well-being as well as critical drivers of sustainable development, peace and security.

\section{METHODOLOGY}

This paper employs the multidisciplinary research method. Multidisciplinary research is a pursuit of truth with the help of numerous specialized branches of learning which aims at achieving a common goal with the aid of knowledge of other disciplines. The study method always tries to understand what is in the mind of the people i.e., how things should be or what needs to be done. The paper relies mainly on research works such as journals, online materials, thesis, dissertations, research journals, newspapers and magazines among others and is to examines the role religion play in promoting sustainable and durable peace aftermath of violent conflict and enhance mutual co-existence among or between different groups in Borno State, as a result of the Boko Haram conflict to avoid future occurrences of such conflict.

\section{THEORETICAL FRAMEWORK}

The study was based on the Durkheim theory of religion and Gramsci's Prisoner's Dilemma. Durkheim viewed religion in his Elementary Forms of the Religious Life, which is certainly the best-known study on the sociology of religion, Within the context of the entire society and acknowledged its place in influencing the thinking and behaviour of the members of society.

Durkheim, accordingly, believes religion is a part of the human condition and the content of religion might be different from society to society over time. Religion will, in some form or another, always be a part of social life. Durkheim 
also argues that religion is the most fundamental social institution, with almost all other social institutions, at some point in human history, being born from it. For these reasons he gave special analysis to this phenomenon, providing a philosophy of religion that is perhaps as provocative as it is rich with insights (Durkheim, 1912).

People tend to separate religious symbols, objects, and rituals, according to Durkheim, which are sacred, from the daily symbols, objects, and routines of existence referred to as the profane. Sacred objects are often believed to have divine properties that separate them from profane objects (ibid). Even in more-advanced cultures, people still view sacred objects with a sense of reverence and awe, even if they do not believe that the objects have some special power. Durkheim also argued that religion is not only concerned with beliefs, rather, encompasses regular rituals and ceremonies on the part of a group of believers, who then develop and strengthen a sense of group solidarity (Durkheim, 1915). Rituals are necessary to bind together the members of a religious group, and they allow individuals to escape from the mundane aspects of daily life into higher realms of experience. Sacred rituals and ceremonies are especially important for marking occasions such as births, marriages, times of crisis, and deaths (Durkheim, 1915).

Durkheim's theory of religion exemplifies how functionalists examine sociological phenomena. According to Durkheim, people see religion as contributing to the general well-being and continuation of society in general. Thus, religion functions to bind society's members by prompting them to affirm their common values and beliefs regularly. However, the critics have questions about his methodology, his interpretation of ethnographic data, or his undermining of traditional religion (Durkheim, 1915).

In Gramsci's view, individuals in society have different beliefs about the statistical relation between their actions in a strategic social interaction and uncertain events that affect their utility. This heterogeneity of beliefs allows for the endogenous emergence of religious institutions (Gilat \& Rizan, 2006). A religious institution is defined by its members' involvement in a costly and observable activity. Members of a religious organization share similar beliefs, tend to cooperate, and face a larger degree of cooperation from society than non-members do. The theory provides the link between individual beliefs, rituals, and social cohesion.

Every theory of religion has the fundamental feature to explain the link between the two most observed aspects of religion, the individual aspect and the social aspect. Individual aspect is referred to as beliefs of the individual about the power or abilities of some supernatural entity. The social aspect on the other hand refers to the observations that most religious rituals are conducted collectively and not individually and that most religions would prescribe how to behave in social interactions. One aspect of religion, which is a crucial part of the theory, involves the interpretation of uncertain events and their relation to actions taken by individuals. All members of the religious group have similar characteristics; Behaviour, Beliefs and Rituals.

Religion allows for social cohesion, while social rituals are the mechanism providing the means to this end. Proponents of the evolutionary approach (Wilson, 2002, Dennett, 2006), explain how religious beliefs and religious organizations might have been shaped by evolutionary forces. In contrast to the evolutionary approach, institutions and beliefs evolve not due to their superior fitness, but as a result of rational behaviour on behalf of individuals. These individuals update their beliefs based on their personal experiences and subsequently choose optimally whether to join a religious organization or not. 


\section{FINDINGS OF THE PAPER}

In peacebuilding vital partners just as social cohesion, religion and religious actors in development and public service arrangement in the public arena assumes a significant job. There was an expanded degree of savagery with religious colourations, after the 9/11 terrorist attack on the World Trade Centre, New York. Since then, multi-religious networks all through the world have had an expansion of open presentations of religious threats. Taking a look at religion through a contention affectability focal point, we see that religion is a social organization that can be both a 'divider' and 'connector' (Ramadhan, 2015). This can be evidenced with religious tension in Nigeria since 1999, the crisis in the Central African Republic, South Sudan, among others.

In many developing social orders, religious establishments are the essential suppliers of public administrations to the networks/communities. These administrations incorporate medical care delivery and instructive administrations through health care delivery places and learning organizations under their administration. In multireligion settings, religious establishments address the security challenges brought about by viciousness that has religious suggestions, the communities keep on connecting in these shared spaces. The connector elements of these spaces make religion in the entirety of its viewpoints; values, structures, assets and so on helpful for peacebuilding and social cohesion (Ramadhan, 2015). As a divider, religion is utilized by culprits to take part in brutality focusing on religious people and structures having a place with different beliefs, bringing about bigotry, dread, doubt and profiling dependent on religious association (Ramadhan, 2015) as had happens in Southern part of Kaduna and some part of Plateau states in Nigeria.

To participate in activities that help networks, for example, the strengthening and social association of the communities for a noble life, religious establishments and people draw their motivation from religious norms and values. All religions have values, standards, culture, and attributes that ensure the prosperity of the individual and humankind by and large. These qualities and standards incorporate individual and local area rights just as access to essential services, for example, education, water, wellbeing, and persuade religious actors to draw in with groups involved in clashes (ICCS, 2019).

The essential tenet of all religions is to recommend morals, standards and qualities that advance social equity and sympathy for those out of luck. Casualties of viciousness, both of strict or in any case are arranged as those out of luck, religion plays a fundamental to mitigate their anguish. Additionally, religion has been an inspiration for activity, explicitly to help reconciliation, social attachment and peacebuilding endeavours. Abrahamic (Jewish, Christian and Islamic) beliefs specifically contain clear statutes and directions for equity and harmony, yet all through mankind's set of experiences, religion has been a significant supporter of treacheries, viciousness, disdain, and prejudice. This duality of potential outcomes in religion should be investigated and perceived (IPF, 2013).

Religious Actors can be significant in forestalling struggles and building serene social orders, and the significance of their commitment is broadly perceived. UN Office on Genocide Prevention and the Responsibility to Protect for example, given a 'Strategy for Religious Leaders and Actors to Prevent Incitement to Violence that Could Lead to Atrocity Crimes,'(Gilat \& Rizan, 2006) in the system of the "Fez process,"(Fletcher et al) which began in 2015 in Morocco with a multi-faith presentation from religious leaders perceiving the 'central job' Faith Actors can play in advancing peaceful co-existence and in forestalling and reacting to atrocity crimes and committing to the 
execution of the strategy (Fletcher, 2015). In this way, the particular habits and routes through which Faith Actors can advance peace cycles incorporate interreligious discourse, advocacy efforts, training, and a comprehensive and allencompassing way to deal with peacebuilding.

In the peacebuilding process, there are a lot of religious/faith-based local and international NonGovernmental Organisations (NGOs) as well as Civil Society Organisations that are working in collaboration with the Federal and State government to promote peacebuilding and social cohesion in Borno state. Some of these NGOs and Civil Society Organisations include; Catholic Relief Services, Christian Aids, Federation of Muslim Women Association (FOMWAN), among others.

The International Alert in collaboration with the Federation of Muslim Women Association (FOMWAN), undertake the following peacebuilding activities in Borno State;

\section{PROMOTING PEACE EDUCATION THROUGH ISLAMIYA SCHOOLS}

Understanding the compatibility of Islamic principles, doctrines and methods of conflict resolution is the core objective of this project. Since the return of democracy in 1999, there is discomfort between the two major religions (Islam and Christianity). This is a result of poor governance associated with corruption, political patronage and a general breakdown of democratic governance. It is of utmost importance to enlighten people on Islamic culture of tolerance and social togetherness, also to increase community awareness of the role of Islam in Peacemaking, to change negative perceptions of western education.

This project aims to increase understanding of the compatibility of Islamic principles and conflict resolution. Since the return of democracy in 1999, there is discomfort between the two major religions (Islam and Christianity), which is fueled by corruption, political patronage and a general breakdown of democratic governance. Greater effort must be made to not only increase community awareness of the role of Islam in Peacemaking but also change negative perceptions of western education.

The two Organisations improve the understanding among parents and pupils of Islamiyah schools on the role education and conflict resolution can play in fostering peace in the community, as well as encourage greater acceptance of this so-called 'western education.

The project put together twenty-four (24) directors of Islamiyah school, alongside twenty (20) female preachers/scholars and also a representative of parents of children of Islamiyah schools were selected, who are hoping to positively influence and encourage to become advocates of the compatibility of Islam and conflict resolution.

\section{ENLIGHTENMENT CAMPAIGN AGAINST STIGMATISATION OF VICTIMS OF BOKO HARAM}

The victims of the Boko Haram who escape from captivity are faced with stigmatization. The community considers them not as partners but as a threat. Therefore, another important peacebuilding effort is how to help address the stereotype and negative perceptions associated with women and girls who have escaped Boko Haram. And also, to accommodate the parents and children of victims who are born out of sexual violence, in Borno state.

As a victim of violent conflict, women and children have been greatly affected by forceful displacement which led to large-scale abduction, recruitment into war as soldiers and sexual violence. The victims of such acts are 
faced with challenges after an escape or rescue, they face suspicion, domestic violence, rejection and even violence by their communities. As a result of the sexual violence, some of the victims got pregnant and deliver during captivity and as such the children born out of the sexual violence face further stigma. Therefore, it is an important issue addressing the obstacles for women and children's reintegration for their survival and long-term peace in the country. The International Alert and the federation of Muslim Woman Association of Nigeria (FOMWAN) considers as an important task to work toward improving understanding of the challenges faced by women and children who are returning home from captivity or escape, by holding community workshops in internally displaced peoples' camps and broadcasting radio programmes on stigma and sexual violence.

The project assists 4,927 women and girls who were survivors of sexual violence by Boko Haram and also conducted workshops to reach 4,889 family members who struggled to reintegrate survivors of sexual violence.

\section{CONFLICT-SENSITIVE REINTEGRATION THROUGH SUPPORTING VULNERABLE COMMUNITIES}

This project supported the reintegration of survivors of violence by Jama'atul ahl al-sunnah li da'awati wal jihad otherwise known as Boko Haram, as well as those internally displaced by the conflict.

The impact of the violence by the insurgency of Boko Haram has left thousands of civilians dead and led to mass displacement across Nigeria and the surrounding countries, threatening the stability of the whole region. Maiduguri, in northeast Nigeria, is home to many of those displaced and faces severe challenges to social cohesion.

The organisations, in their peacebuilding efforts, worked in three internally displaced peoples (IDPs) camps and one host community in Maiduguri, and another community in nearby Bama, to help those affected by the violence reintegrate back into society and move forward with their lives.

\section{CONCLUSION AND RECOMMENDATION}

counteraction to compromise and long term peaceful and comprehensive social orders, Faith Actors should be available and dynamic at all phases of contention. There are a few areas wherein faith actors are especially connected with and focused on, for example, countering radicalism and endeavours for interreligious agreement as to the case with the Federation of Muslim Women Association of Nigeria (FOMWAN) and the Christian Aid Council (CAC). Complementarity between various religious elements' approaches in ways to deal with building social attachment is important. As such, cultivating social cohesion requires the integration of security, harmony and advancement activities between various religious groups. community advancement projects that address concrete collective necessities (shared interests across gatherings) can work as indirect, yet basic, openings for between groups participation and cooperation. Consequently, maybe the main capacity that peacebuilders can play is to distinguish and give the same number of places, organizations, and arena for collaboration and commitment on manners by which social orders rising out of conflict can in their communication decide the manners by which more interdependence reliance and bridging social capital can be locally encouraged. 


\section{IN PEACEBUILDING AND SOCIAL COHESION, THE FOLLOWING RECOMMENDATIONS ARE MADE BY RELIGIOUS ACTORS;}

- Promoting resistance and passing messages of peaceful co-existence towards other religious networks;

- Building unions by working in and through with other religious pioneers;

- To build attention to social attachment through the Use strict based schools and training organizations;

- By censuring demonstrations of violence or violent talk dependent on strict contrasts through the issuance of joint articulations;

- Engaging in exchange to building synergistic associations with different partners;

- Ensuring powerful correspondence frameworks between various strict gatherings;

- Identify and use instruments that help solidarity and managing conflict; and

- Support interpersonal organizations that unite isolated groups.

\section{REFERENCE}

Abubakar, B., (2017) Origin and Meaning of Maiduguri. Research Gate, https://www.researchgate.net/publication/318215165.

Abubakar, A., (2016) The Role of the Military in Restoring Peace to Maiduguri, Borno State. National Open University of Nigeria, Lagos.

Dennett, D. C., (2006), Breaking the Spell: Religion as a Natural Phenomenon, Penguin, Allen Lane.

Durkheim, E., (1912) The Elementary Forms of Religion, reprinted in A Reader in the Anthropology of Religion, Blackwell publishing, 2005.

Durkheim, E., (1915) The Elementary Forms of the Religious Life, George Allen \& Unwin Ltd Ruskin House Museum Street. Ebook Edition 2015

Federal Government of Nigeria-FGN, (2016) North-East Nigeria: Recovery and Peacebuilding Assessment Report, Synthesis Paper, Vol. I.

Fletcher, D. C., Catherine, R. O., and Timothy, D. S., (2014) Religion, Peacebuilding, and Social Cohesion in ConflictAffected Countries, Research Report.

Fletcher, D. C., Catherine, R. O., and Timothy, D. S., (2015) Religion and Social Cohesion in Nigeria: Frustration, Polarisation, and Violence. Case Study overview.

Gilat, L., \& Razin, R., (2006), A Theory of Religion: Linking Individual Beliefs, Rituals, and Social Cohesion.

Inter-Faith Peace Forum Phase II- IPF, (2013) The Role of Religious Leaders in Maintaining Sustainable Peace and Social Cohesion in Tanzania.

International Conference on Cohesive Societies- ICCS, (2019) Global Leaders in Peace and Religious Harmony to Address Key Challenges Facing Social Cohesion.

Ramadhan, S., (2017) Inter-Religious Action as a Force for Peace. The Journal of Social Encounter, Vol. 1, ISS 1, Article 5, 54-62. 
United State Agency for International Development-USAID, (2009) Religion, Conflict and Peacebuilding. An Introductory Programme Guide.

Wilson, D. S., (2002), Darwin's Cathedral, Chicago University Press.

www.crs.org/our-work-overseas/proram-areas/justice-and-peacebuilding access 23/08/2021 